\title{
KINETICS MODELING AND ISOTHERMS FOR ADSORPTION OF NITRATE FROM AQUEOUS SOLUTION BY WHEAT STRAW
}

\section{MODELAGEM CINÉTICA E ISOTERMAS PARA ADSORÇÃO DE NITRATO DE SOLUÇÃO AQUOSA POR PALHA DE TRIGO}

\section{Hedieh Ahmadpari}

Graduate of Irrigation and Drainage, Department of Irrigation and Drainage, College of Aburaihan, University of Tehran, Iran. Email:

h.ahmadpari@gmail.com

Mohsen Eskafi Noghany

Expert, Department of irrigation and drainage, College of Aburaihan, University of Tehran, Iran. Email:m_skafi@ut.ac.ir

\section{Behnam Rigi Ladez}

M.Sc. Student of Irrigation and Drainage, University of Zabol, Iran, Email: behnam.rigi@gmail.com

\section{Babak Mehrparvar}

Master of Civil EngineeringHydraulic Structures, University of Mohagheg Ardebili, Iran.Email: Babak_mehrparvar@yahoo. com

\section{Saeed Momeni}

Expert of Central Laboratory, College of Aburaihan, University of Tehran, Iran. Email: s_momeni@ut.ac.ir

\section{RESUMO}

O nitrato é uma substância química incolor e inodora, com uma formulação química de NO3 e massa média de 62,0049 g / mol. De acordo com um anúncio da organização mundial de saúde (OMS), a quantidade padrão de nitrato na água potável é de no máximo $50 \mathrm{ml} / \mathrm{L}$ (com base no nitrato). O nitrato entra no corpo e é transformado em nitrito pelas bactérias do sistema digestivo, depois entra no sistema circulatório e oxida o ferro existente na hemoglobina do sangue, que converte a capacidade de ferro de 2 para 3 . Como resultado desse processo, a hemoglobina é convertida em Metahemoglobina, que tem muito menos capacidade na entrega de oxigênio. Portanto, os tecidos não podem receber oxigênio suficiente e causam uma doença chamada "metahemoglobinemia". O objetivo deste estudo foi investigar a remoção de nitrato usando palha de trigo e determinar as isotermas e cinéticas de adsorção. Neste estudo, soluções de nitrato foram preparadas a partir de sal de nitrato de potássio. Os valores de $\mathrm{pH}$ das soluções foram ajustados por $\mathrm{NaOH}$ e $\mathrm{HCl}$ a uma concentração de $0,1 \mathrm{~mol} / \mathrm{L}$. O pH da solução foi ajustado para diferentes valores (4 a 13). Modelos cinéticos de Ho et al e Lagergren foram utilizados para descrever os dados. Modelos isotérmicos de Langmuir e Freundlich foram utilizados para descrever os dados. Os resultados mostraram que a capacidade máxima de palha de trigo na adsorção de nitrato ocorreu em $\mathrm{pH}=6$ e tempo de contato de 140 minutos. Modelos de equilíbrio (Langmuir e Freundlich) e não-equilíbrio (Ho et al. E Lagergren) foram utilizados para investigar o processo de adsorção. A comparação dos coeficientes de determinação entre os dados medidos e o valor obtido do modelo de Ho (R2 = $0,97)$ e do modelo de Lagergren $(\mathrm{R} 2=0,91)$ mostrou que o modelo de Ho descreve melhor os dados experimentais. Além disso, a comparação da isoterma de Langmuir e Freundlich para adsorção de nitrato por palha de trigo mostrou que a isoterma de Freundlich $(\mathrm{R} 2=0,98)$ foi mais adequada que a isoterma de Langmuir $(\mathrm{R} 2=0,83)$ na descrição do processo de adsorção.

Palavras-chave: Nitrato, Ho et al., Lagergren, Langmuir, Freundlich.

\section{ABSTRACT}

Nitrate is a colorless, odorless chemical substance with a chemical formulation of $\mathrm{NO}_{3}{ }^{-}$and average mass of $62.0049 \mathrm{~g} / \mathrm{mol}$. According to an announcement of the world health organization (WHO), the standard amount of nitrate in potable water is at most $50 \mathrm{ml} / \mathrm{L}$ (based on nitrate). Nitrate enters into the body and is transformed to nitrite by digestive system's bacteria, then enters to the circulatory system and oxides the exiting iron in Hemoglobin of blood which converts the iron capacity from 2 to 3 . As a result of this process Hemoglobin is converted to Methemoglobin which has far more less capacity in oxygen delivery. Therefore, the tissues cannot receive sufficient oxygen and it causes a disease called "Methemoglobinemia". The objective of this study was to investigate the nitrate removal using wheat straw and determining the adsorption isotherms and kinetics. In this study, nitrate solutions were prepared from potassium nitrate salt. The $\mathrm{pH}$ values of the solutions were adjusted by $\mathrm{NaOH}$ and $\mathrm{HCl}$ at a concentration of 0.1 $\mathrm{mol} / \mathrm{L}$. The $\mathrm{pH}$ of the solution was adjusted to different values (4 to 13). Kinetics 
models of Ho et al and Lagergren were used to describe the data. Isotherm models of Langmuir and Freundlich were used to describe the data. The results showed that the maximum capacity of wheat straw in nitrate adsorption occurred at $\mathrm{pH}=6$ and contact time 140 minutes. Equilibrium models (Langmuir and Freundlich) and non-equilibrium (Ho et al. and Lagergren) were used to investigate the adsorption process. Comparing the determination coefficients between measured data and obtained value from Ho's model $\left(\mathrm{R}^{2}=0.97\right)$ and Lagergren model $\left(\mathrm{R}^{2}=\right.$ 0.91) showed that the Ho's model describes experimental data better. Also, comparing the Langmuir and Freundlich isotherm for nitrate adsorption by wheat straw showed that Freundlich isotherm $\left(\mathrm{R}^{2}=0.98\right)$ was more proper than Langmuir isotherm $\left(\mathrm{R}^{2}=0.83\right)$ in describing adsorption process.

Keywords: Nitrate, Ho et al., Lagergren, Langmuir, Freundlich 
Revista Tecnologia e Ambiente, v. 25, 2019, Criciúma, Santa Catarina/SC ISSN Eletrônico 2358-9426 e ISSN Impresso 1413-8131

\section{Introduction}

Nitrate is one of the most common chemical pollutants in groundwater. Increasing the pollution of surface water and groundwater by nitrate is an important motive for finding solutions with minimum environmental impacts to eliminate them. The surface adsorption method is considered as one of the most effective methods for the removal of nitrate from aqueous media due to relatively low operating costs and the lack of final treatment at all times.

In the surface adsorption process, the price of consuming adsorbent is one of the most important factors in the economic process. For this reason, most researchers are trying to make and choose a cheap adsorbent in the surface adsorption process. Therefore, the use of natural, low-cost and environmentally friendly adsorbents, is considered as an effective tool for achieving sustainable development. So far, much research has been done on the removal of nitrate from aqueous solutions with various adsorbents, which some of them are referred to here. Farasati et al. (2013) the effect of sugarcane straw and Phragmites australis anion exchanger nano adsorbents investigated for removal of nitrate from aqueous solutions.

The effects of operating conditions such as $\mathrm{pH}$, contact time, adsorbent loading, initial anion concentration, and the presence of competitive ions on the adsorption performances were examined. The results showed that the equilibrium time was 2 hours and the $\mathrm{pH}$ was 6 . With $\mathrm{pH}$ of the solution varying from 2 to 10 , the nitrate removal efficiency for sugarcane straw and Phragmites australis nano adsorbent increased up to maximum of $45 \%$ to $76 \%$ and $60 \%$ to $86 \%$ reached at $\mathrm{pH}$. With an increase in the nitrate concentration from 5 to $120 \mathrm{mg} / \mathrm{L}$, the removal efficiency decreased from $86 \%$ to $66 \%$ and $90 \%$ to $67 \%$ for sugarcane straw and Phragmites australis nano adsorbent, respectively. For Phragmites australis nano adsorbent, with an increase in the adsorbent dosage from $0.1 \mathrm{~g}$ to $0.3 \mathrm{~g}$, the removal efficiency increased from $60 \%$ to $85 \%$, but remained almost unchanged when adsorbent dosage ranged from $0.3 \mathrm{~g}$ to $1 \mathrm{~g}$.

For sugarcane straw nano adsorbent as the adsorbent dosage increased from $0.1 \mathrm{~g}$ to $0.5 \mathrm{~g}$, the removal efficiency of nitrate increased from $45 \%$ to $75 \%$, but remained almost unchanged for the increase of $0.5 \mathrm{~g}$ to $1 \mathrm{~g}$. Adsorption kinetics of nitrate ions could most successfully be described by Freundlich isotherm.

This study indicated that sugarcane straw and Phragmites australis nano adsorbents could be used for the removal of nitrate ions in water treatment and Phragmites australis nano adsorbent has higher adsorption than sugarcane straw nano adsorbent for nitrate removal. Safdari et al (2015) investigated the efficacy of date kernel ash on removal of nitrate from aqueous solutions. In this experimental study which was conducted in vitro, the effect of initial nitrate concentration (50, 100, and $150 \mathrm{mg} / \mathrm{L})$, initial $\mathrm{pH}(3,5,7$, and 9), time (15, 30, 60, 120, and 180 minutes), and weight of 
adsorbent $(0.4,0.6$, and $0.8 \mathrm{~g})$ was investigated. The nitrate concentration was measured using spectrophotometer at two wavelengths $220 \mathrm{~nm}$ and $275 \mathrm{~nm}$. All tests and samples analysis was done per textbooks on standard methods of sewage.

The adsorbent dose increase from $0.4 \mathrm{~g}$ to $0.8 \mathrm{~g}$ in $100 \mathrm{~mL}$ nitrate solution with concentrations of 50 and $100 \mathrm{mg} / \mathrm{L}$ caused increase in absorption efficiency respectively from $75 \%$ to $91 \%$ and from $53 \%$ to $65 \%$. Increase in solution's initial $\mathrm{pH}$ from 3 to 9 caused decrease in the absorption efficiency from $52 \%$ to $8 \%$. The results obtained in this study obey Freundlich isotherm $\left(\mathrm{R}^{2}=0.98\right)$ and nitrate absorption obeys the pseudo-second order kinetics model $\left(\mathrm{R}^{2}=0.999\right)$. Arbabi et al (2016) investigated the almond shells magnetized by iron nano-particles for nitrate removal from aqueous solution. In This experimental study morphology of synthesized adsorbent was analyzed using FESEM and BET techniques.

The effective parameters on nitrate ion absorption process such as $\mathrm{pH}(4-8)$, the amount of absorbent $(0.25-1 \mathrm{~g} / \mathrm{L})$, the initial concentration of nitrate ions $(25-400 \mathrm{mg} / \mathrm{L})$ and contact time $(20$ $100 \mathrm{~min}$ ) were investigated. In this research, Taguchi method was applied for determining the sample size and statistical analysis. Findings of FESEM and BET techniques confirmed that magnetic nanoparticles size and specific surface area in the synthesized absorbent were 23-27 nm and $105.480 \mathrm{~m}^{2} / \mathrm{g}$, respectively. At optimal $\mathrm{pH} 4$ and equilibrium time of $20 \mathrm{~min}$, absorption efficiency increased with absorbent increase by $1 \mathrm{~g} / \mathrm{L}$ and reduction in the initial concentration of nitrate ions $(85.86 \pm 4.6)$.

The results of adsorption equilibrium isotherms showed that nitrate absorption process follows the Langmuir isotherm $\left(\mathrm{R}^{2}=0.924\right)$. Divband et al. (2014) investigated the kinetics and isotherm adsorption nonlinear models for nitrate by titanium dioxide nano particles. The results showed that the maximum capacity of titanium dioxide nanoparticles in nitrate adsorption occurred at $\mathrm{pH}=5$ and contact time 120 minutes.

Equilibrium models (Langmuir and Freundlich) and non-equilibrium (Ho et al. and Lagergren) were used to investigate the adsorption process. Comparing the determination coefficients between measured data and obtained value from Ho's model $\left(\mathrm{R}^{2}=0.98\right)$ and Lagergren model $\left(\mathrm{R}^{2}=0.95\right)$ showed that the Ho's model describes experimental data better. Also, comparing the Langmuir and Freundlich isotherm for nitrate adsorption by titanium dioxide nanoparticles showed that Freundlich isotherm $\left(\mathrm{R}^{2}=0.99\right)$ was more proper than Langmuir isotherm $\left(\mathrm{R}^{2}=0.91\right)$ in describing adsorption process. Naseri et al. (2013) evaluated the performance of modified pumice on removal nitrate from aqueous solution.

This fundamental and practical study was performed in batch conditions and roomtemperature. Effects of the process parameters such as contact time, initial concentration and $\mathrm{pH}$ 
were investigated. In this study, Langmuir and Freudlich isotherms was survey to adsorption reactions and to calculate the equilibrium constant. Residual nitrate concentrations determined in 220 and $275 \mathrm{~nm}$ using a spectrophotometer (UV/VIS) Shimadzo-1700, Japan. Results of literature indicated that removal nitrate depend on Freundlich $\left(\mathrm{R}^{2}>0.998\right)$. In the study kf was 0.14 and amount of adsorbed nitrate was $\mathrm{qm}(\mathrm{mg} / \mathrm{g})=0.65$ for mass unit of modified Pumice.

The pseudo second-order is found in the best fitness with the kinetics data. Marzi et al. (2015) investigated the characteristics of nitrate sorption onto activated carbon. In this study, nitrate sorption kinetics and isotherms, as well as the effects of contact time, initial concentration, $\mathrm{pH}$ and temperature on nitrate sorption onto activated carbon were investigated.

The surface characteristics of activated carbon were also studied, through FTIR and SEM techniques. Two simplified kinetics models, namely: pseudo-first and pseudo-second orders were tested to investigate the sorption mechanisms and while two isotherm models namely Freundlich and Langmuir employed to describe the equilibrium sorption of nitrate onto activated carbon. The results revealed that the amount of nitrate sorption increased with time and reached its maximum after ten minutes past. Maximum nitrate sorption occurred in a neutral $\mathrm{pH}$ figure, and with either increase or decrease in the $\mathrm{pH}$ level, the amount of sorption being decreased.

The amount of nitrate sorption increased with a decrease in temperature, level, the depicting the exothermic nature of sorption. A comparison of the coefficient of determination of the fitted equations indicated that pseudo-second order equation $\left(\mathrm{R}^{2}=1.000\right)$ was better fitting than pseudofirst order equation $\left(\mathrm{R}^{2}=0.839\right)$ for description of nitrate sorption data. Sorption isotherm was proper, as described by Langmuier model $\left(\mathrm{R}^{2}=0.998\right)$ and the maximum sorption parameter equaled $8.93 \mathrm{mg} / \mathrm{g}$ of activated carbon. Nemati sani et al. (2014) investigated the removal of nitrate from aqueous solutions using Saccharomyces cerevisiae biosorbent.

This research is a laboratory study. These researchers studied the influence of process variables such as adsorbent dose, initial $\mathrm{NO}_{3}$ concentration, $\mathrm{pH}$ and contact time on adsorption process. Langmuir and Freundlich isotherms and adsorption kinetics was also studied. Most of the experiments were done with $50 \mathrm{mg} / \mathrm{L}$ of initial nitrate. Our results showed that the maximum $\mathrm{NO}_{3}$ removal efficiency was achieved at $\mathrm{pH}=4$, adsorbent dose $1 \mathrm{~g} / 100 \mathrm{ml}$ and contact time $20 \mathrm{~min}$. The result showed that the nitrate adsorption by the Saccharomyces cerevisiae followed Langmuir isotherm and second- order kinetics. Norisepehr et al. (2013) compared the chitosan function as adsorbent for nitrate removal using synthetic aqueous solution and drinking water. This experimental study is applied to the nitrate removal using chitosan in laboratory scale at ambient temperature and the design of the system was Batch. 
Effects of parameters such as $\mathrm{pH}$, contact time, initial concentration and adsorbent concentration of nitrate on nitrate removal from aqueous solution was studied. Function of chitosan in synthetic aqueous solution and drinking water according to the slurry system results, the optimum condition was obtained at $\mathrm{pH}=4,20$ min contact time and increasing the initial concentration of nitrate enhance the adsorption capacity of chitosan. Also optimum dosage of adsorbent was obtained at $0.5 \mathrm{~g} / \mathrm{L}$.

The data obtained from the experiments of adsorbent isotherm were analyzed using Langmuir and Freundlich isotherm models. The Langmuir equation was found to be the best fitness with the experimental data $\left(\mathrm{R}^{2}>0.93\right)$. The objective of this study was to investigate the nitrate removal using wheat straw and determining the adsorption isotherms and kinetics.

\section{Materials and methods}

Wheat straw was obtained from farms of Tehran province and in order to increase the accuracy of the experiment, weed straw was removed from the straw. After clearing the wheat straw, the grass was washed four times with water and twice with distilled water and dried in an oven at $80{ }^{\circ} \mathrm{C}$ for 24 hours. Storage solutions (1000 mg/L) were prepared using potassium nitrate salt. Then solutions were made at concentrations of $1,2,5,10,20,40$ and $50 \mathrm{mg} / \mathrm{L}$ of the main storage solution. In all experiments, the volume of the solution used will be $50 \mathrm{ml}$.

The $\mathrm{pH}$ values of the solutions were adjusted by $\mathrm{NaOH}$ and $\mathrm{HCl}$ at a concentration of 0.1 mol/L. In order to determine the optimum $\mathrm{pH}$ of nitrate adsorption by wheat straw, first 10 beaker of $200 \mathrm{ml}$ washed with distilled water and 3 molars nitric acid solution and in each beakers is poured 1 gram of adsorbent. Then add $100 \mathrm{ml}$ of solution with a concentration of $20 \mathrm{mg} / \mathrm{L}$ to each beaker. The $\mathrm{pH}$ of the solution was adjusted to different values (4 to 13).

The solution is placed at room temperature for 24 hours on an incubator shaker at a speed of $150 \mathrm{rpm}$. After this time, the adsorbent separation from the solution is carried out by the filter paper and the concentration of the solution is determined. Then the amount and adsorption efficiency are determined from relations 1 and 2 (Bhatnagar et al., 2010; Hekmatzadeh et al., 2013).

$$
\begin{aligned}
& \mathrm{q}_{\mathrm{e}}=\left(\left(\mathrm{C}_{\mathrm{o}}-\mathrm{C}_{\mathrm{e}}\right) /(\mathrm{m})\right) \times \mathrm{V} \\
& \% \mathrm{R}=\left(\left(\mathrm{C}_{\mathrm{o}}-\mathrm{C}_{\mathrm{e}}\right) /\left(\mathrm{C}_{\mathrm{o}}\right)\right) \times 100
\end{aligned}
$$

Initial concentration of nitrate in solution $(\mathrm{mg} / \mathrm{l})=\mathrm{C}_{\mathrm{o}}$; Concentration of nitrate in solution after mixing time $(\mathrm{mg} / \mathrm{l})=\mathrm{C}_{\mathrm{e}}$; Adsorbent $\operatorname{mass}(\mathrm{g})=\mathrm{m}$; Volume of the solution $(\mathrm{L})=\mathrm{V}$; Amount of $\operatorname{adsorption}(\mathrm{mg} / \mathrm{g})=\mathrm{q}_{\mathrm{e}} ;$ Adsorption efficiency $(\%)=\mathrm{R}$ 
For optimal adsorbent mass determination experiments, the amount of 1, 2, 3, 4, 5, 10, 15, $20,30,40$ and $50 \mathrm{~g}$ of wheat straw is added to $100 \mathrm{~mL}$ of solution at a concentration of $20 \mathrm{mg} / \mathrm{L}$. The $\mathrm{pH}$ of the solution is adjusted to the optimum amount and then placed on a shaker at $150 \mathrm{rpm}$ for $120 \mathrm{~min}$. After this time, the adsorbent separation from the solution is carried out by the filter paper and the concentration of the solution is determined. Then the amount and adsorption efficiency are determined from relations 1 and 2.

Obtaining adsorption isotherm is a suitable method for determining adsorbent potentials. The adsorption isotherm curves are able to quantitatively evaluate the behavior and adsorption performance of natural adsorbents for a substance at a time. Equilibrium adsorption isotherms are equations that show the distribution of matter adsorbed between the soluble and absorbed phase in the equilibrium condition and is a characteristic for the system at a specific temperature.

To describe the equilibrium state, two parameters qe and $\mathrm{Ce}$ are used, where qe is the amount of matter adsorbed per unit weight of the adsorbent and Ce is the concentration of the remaining part in the solution. To perform adsorption isotherm tests, add 1 gram of wheat straw to $100 \mathrm{ml}$ of solution at various concentrations $(1,2,5,10,20,40$ and $50 \mathrm{mg} / \mathrm{L})$, and the shaker is placed at a speed of $150 \mathrm{rpm}$ for 120 minutes.

After this time, the adsorbent separation from the solution is carried out by the filter paper. Then the Langmuir and Freundlich models are used to describe the data. The Langmuir model shows a monolayer adsorption on the homogeneous surface without the reaction between adsorbed molecules and uniform energies of adsorption on the surface. The Langmuir adsorption isotherm is represented by Equation 3 (Langmuir, 1916).

$$
q_{e}=\frac{q_{e} \mathrm{~b} c_{e}}{k_{I}+k_{i} c_{e}}
$$

Concentration of adsorbed substance in equilibrium condition in the liquid phase $(\mathrm{mg} / \mathrm{L})=\mathrm{Ce}$; The amount of ion adsorbed per unit mass of the adsorbent in equilibrium condition $(\mathrm{mg} / \mathrm{g})=\mathrm{qe}$; Adsorption capacity in solid phase $(\mathrm{mg} / \mathrm{g})=\mathrm{b}$; Adsorption coefficient=k

Freundlich isotherm is an experimental model for explaining the multilayer adsorption by heterogeneous energy distribution with the reaction between the adsorbed molecules. The Freundlich adsorption isotherm is represented by Equation 4 (Freundlich, 1906).

$$
q_{e}=\frac{x}{m}=k_{f} c_{e}^{\frac{1}{n}}
$$

The isotherm coefficient in relation to the amount of adsorbed according of $\mathrm{L} / \mathrm{g}=\mathrm{k}_{\mathrm{f}}$; The adsorption intensity is that changes with the non-uniformity of the material $=1 / n$ 
One of the important studies in the adsorption process is the study of the effect of contact time on adsorption amount, which is known as kinetics studies. In order to study the mechanisms for controlling the adsorption process, the first-order kinetics models (Lagergren) and second-order kinetics models (Ho et al) will be investigated. The Lagergren kinetics model is represented by Equation 5 (Lagergren, 1898).

$$
\log \left(\mathrm{q}_{\mathrm{e}}-\mathrm{q}_{\mathrm{t}}\right)=\log \mathrm{q}_{\mathrm{e}}-\left(\mathrm{k}_{\mathrm{t}} \mathrm{t} / 2.303\right)
$$

The equilibrium adsorption capacity as $\mathrm{mg} / \mathrm{g}=\mathrm{q}_{\mathrm{e}}$; The amount of nitrate adsorbed at time $\mathrm{t}$ according to $\mathrm{mg} / \mathrm{g}=\mathrm{qt}$; The adsorption constant is according to $\min ^{-1}=\mathrm{k}$ ।

The Ho et al. kinetics model is represented by Equation 6 (Lagergren, 1898).

$$
\frac{t}{q_{e}}=\frac{1}{k_{2} q_{e}^{2}+\frac{t}{q_{e}}}
$$

The equilibrium adsorption capacity as $\mathrm{mg} / \mathrm{g}=\mathrm{q}_{\mathrm{e}}$; The amount of nitrate adsorbed at time $\mathrm{t}$ according to $\mathrm{mg} / \mathrm{g}=\mathrm{q}_{\mathrm{t}}$; The adsorption constant is according to $\mathrm{g} \cdot \mathrm{mg}^{-1} \mathrm{~min}^{-1}=\mathrm{k}_{2}$

The efficiency of all models was evaluated using Root Mean Square Error (RMSE) and Coefficient of Determination $\left(\mathrm{R}^{2}\right)$ statistic parameters. The statistical indices RMSE and $\mathrm{R}^{2}$ are defined as equations 7 and 8 .

$$
\begin{aligned}
& \text { RMSE }=\sqrt{\frac{\sum_{i=1}^{n}\left(s_{i}-o_{i}\right)^{2}}{n}} \\
& R^{2}=\left(\frac{\sum_{i=1}^{n}\left(o_{i}-\bar{o}\right)\left(s_{i}-\bar{s}\right)}{\sqrt{\sum_{i=1}^{n}\left(o_{i}-\bar{b}\right){ }^{2} \times \sum_{i=1}^{n}\left(s_{i}-\bar{s}\right)^{2}}}\right)^{2}
\end{aligned}
$$

The RMSE value indicates how much the predictions have estimated the measurements more or less. Whatever the value of the indicator is closer to zero, the better (the difference between the predicted and measured values is lower) (Ahmadpari et al., 2019). The well-known $\mathrm{R}^{2}$ statistic, or the (multiple) coefficient of determination, pertains to the proportion of variance in the response variable explained by a fitted model relative to simply taking the mean of the response. In other words, it describes how well the model fits the data. An $\mathrm{R}^{2}$ close to 1 implies an almost perfect relationship between the model and the data, whereas an $\mathrm{R}^{2}$ close to 0 implies that just fitting the mean is equivalent to the model fitted (Saunders et al., 2012).

\section{Results and discussion}

Figure 1 shows the effect of $\mathrm{PH}$ on nitrate adsorption. As already mentioned, the range of $\mathrm{PH}$ is 4 to 13 . Figure 1 shows that the maximum efficiency of nitrate adsorption $(92 \%)$ is at $\mathrm{pH}=6$. 
With increasing $\mathrm{pH}$, more than 6, the adsorption efficiency was reduced and at least it (12\%) was observed at $\mathrm{pH}=13$. In low $\mathrm{pH}$ levels, the adsorbent surface has a positive charge, which increases the adsorbent tendency to absorb nitrate ions that have a negative charge (Olgun et al., 2013). In high $\mathrm{pH}$ levels, $\mathrm{OH}^{-}$ions compete with nitrate ions to absorb in adsorbent positions and by occupying adsorbent sites, reduce the adsorbent capacity in nitrate adsorption (Divband et al., 2014). In addition, at high $\mathrm{pH}$ values, negative charge increases in the adsorbent surface and reduce the nitrate adsorption efficiency.

Figure 1-Changes in $\mathrm{pH}$ relative to nitrate adsorption efficiency by wheat straw

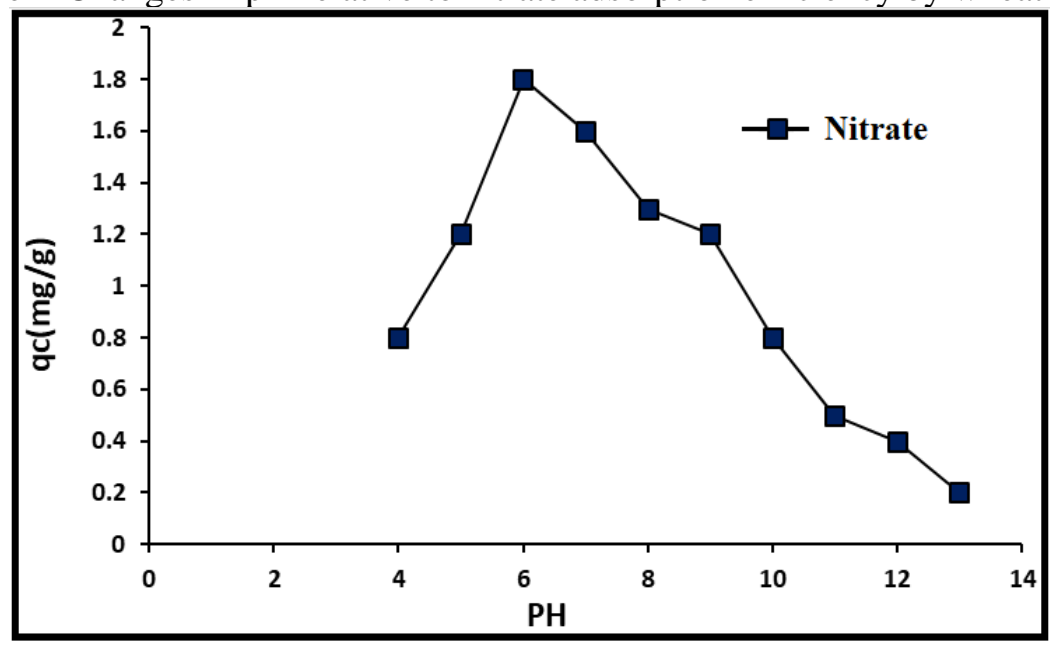

Figure 2 shows the effect of adsorbent amount on the adsorption efficiency of nitrate with a concentration of $20 \mathrm{mg} / \mathrm{L}$. Experiments were performed in solutions of $100 \mathrm{ml}$ volume. The results showed that by increasing the amount of adsorbent from $1 \mathrm{~g}$ to $10 \mathrm{~g}$, the adsorbent contact increases with nitrate ions and increases their adsorption. By increasing the amount of adsorbent (greater than $10 \mathrm{~g}$ ), the nitrate adsorption efficiency is reduced. This is due to the fact that, by increasing the amount of adsorbent in the solution, the specific surface of the adsorbent particles decreases and the nitrate adsorption efficiency decreases by this adsorbent.

Figure 2-Changes in adsorbent amount relative to nitrate adsorption efficiency by wheat straw

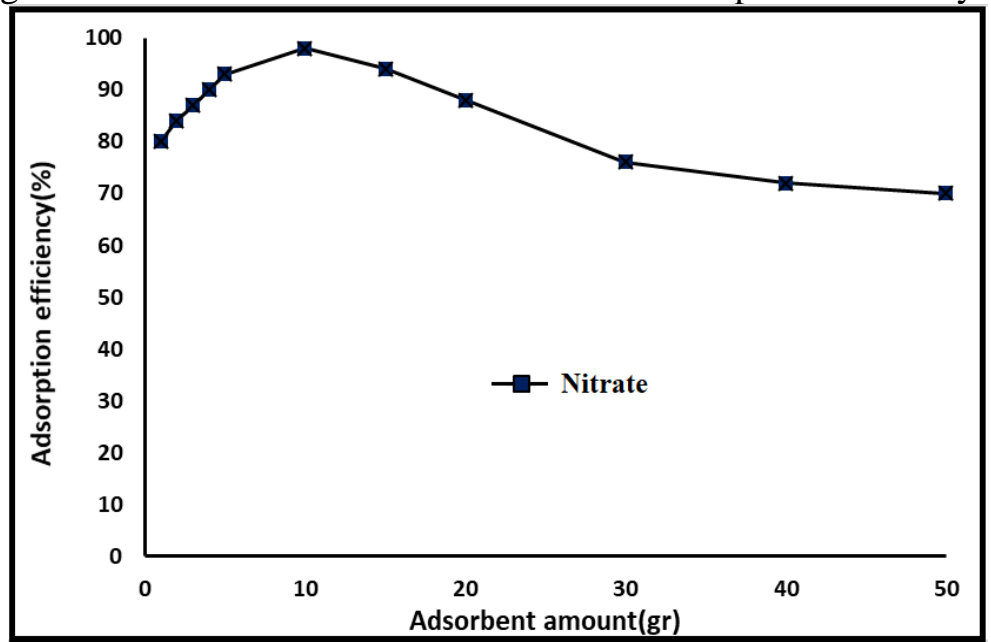


Figure 3 shows the fitting of kinetics models of nitrate adsorption by wheat straw in optimum $\mathrm{pH}$. Also, the fitting results of the models are presented in Table 1. The comparison of the results shows that Ho et al. model with better determination coefficient $\left(R^{2}=0.97\right)$ and less root mean square error $(\mathrm{RMSE}=0.08)$ compared to the Lagergren model $\left(\mathrm{R}^{2}=0.91\right.$, $\left.\mathrm{RMSE}=0.11\right)$ describes experimental data better. Also, the results showed that the Lagergren model was more successful in estimating the value of $\mathrm{q}_{\mathrm{e}}(1.85 \mathrm{mg} / \mathrm{g})$ compared to Ho et al. model $(1.94 \mathrm{mg} / \mathrm{g})$. According to Fig. 3, the amount of adsorption increases with increasing contact time. Also, by increasing the contact of nitrate ions with adsorbent, the amount of adsorption increases. At 140 min after contact of wheat straw and nitrate solution, the adsorption process reaches equilibrium. Increasing the contact time after this time does not affect the amount of adsorption.

Table 1-Parameters of kinetics models of nitrate adsorption by wheat straw

\begin{tabular}{|l|l|l|l|l|l|l|l|l|}
\hline \multirow{2}{*}{ qexperimental } & \multicolumn{4}{|c|}{ Lagergren model } & \multicolumn{4}{c|}{ Ho et al. model } \\
\cline { 2 - 9 } & RMSE & $\mathrm{R}^{2}$ & $\mathrm{~K}_{1}$ & $\mathrm{q}_{\mathrm{e}}$ & RMSE & $\mathrm{R}^{2}$ & $\mathrm{~K}_{2}$ & $\mathrm{q}_{\mathrm{e}}$ \\
\hline 1.87 & 0.11 & 0.91 & 0.05 & 1.85 & 0.08 & 0.97 & 0.04 & 1.94 \\
\hline
\end{tabular}

Figure 3 - The fitting of kinetics models on experimental data of nitrate adsorption by wheat straw

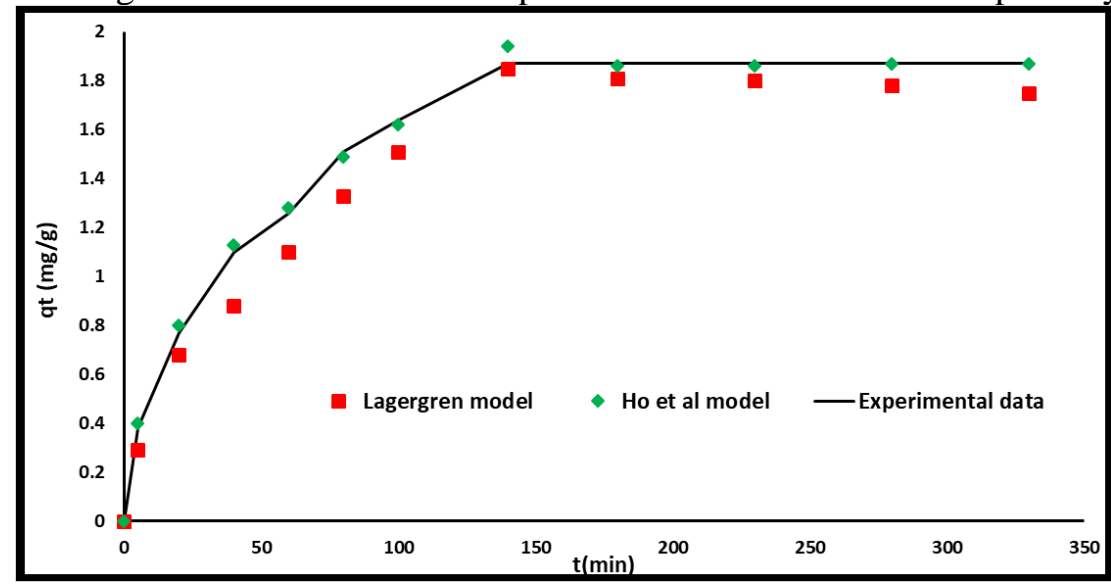

Figure 4 shows the fitting of isotherm models of nitrate adsorption by wheat straw. Also, the fitting results of the models are presented in Table 2. Comparing the Langmuir and Freundlich isotherm for nitrate adsorption by wheat straw showed that Freundlich isotherm $\left(\mathrm{R}^{2}=0.98\right.$, RMSE $=0.15)$ was more proper than Langmuir isotherm $\left(\mathrm{R}^{2}=0.83, \mathrm{RMSE}=0.43\right)$ in describing adsorption process. The parameter $\mathrm{b}$ in the Langmuir model expresses the maximum adsorbent capacity for nitrate adsorption at its surface. In this study, this parameter was $13.36 \mathrm{mg} / \mathrm{g}$.

Table 2-Parameters of isotherm models of nitrate adsorption by wheat straw

\begin{tabular}{|l|l|l|l|l|l|l|l|}
\hline \multicolumn{3}{|c|}{ Freundlich isotherm } & \multicolumn{4}{c|}{ Langmuir isotherm } \\
\hline RMSE & $\mathrm{R}^{2}$ & $\mathrm{~K}_{\mathrm{f}}$ & $\mathrm{n}$ & $\mathrm{RMSE}$ & $\mathrm{R}^{2}$ & $\mathrm{~K}_{\mathrm{L}}$ & $\mathrm{b}$ \\
\hline 0.15 & 0.98 & 0.65 & 0.64 & 0.43 & 0.83 & 0.17 & 13.36 \\
\hline
\end{tabular}


Figure 4 - The fitting of isotherm models on experimental data of nitrate adsorption by wheat straw

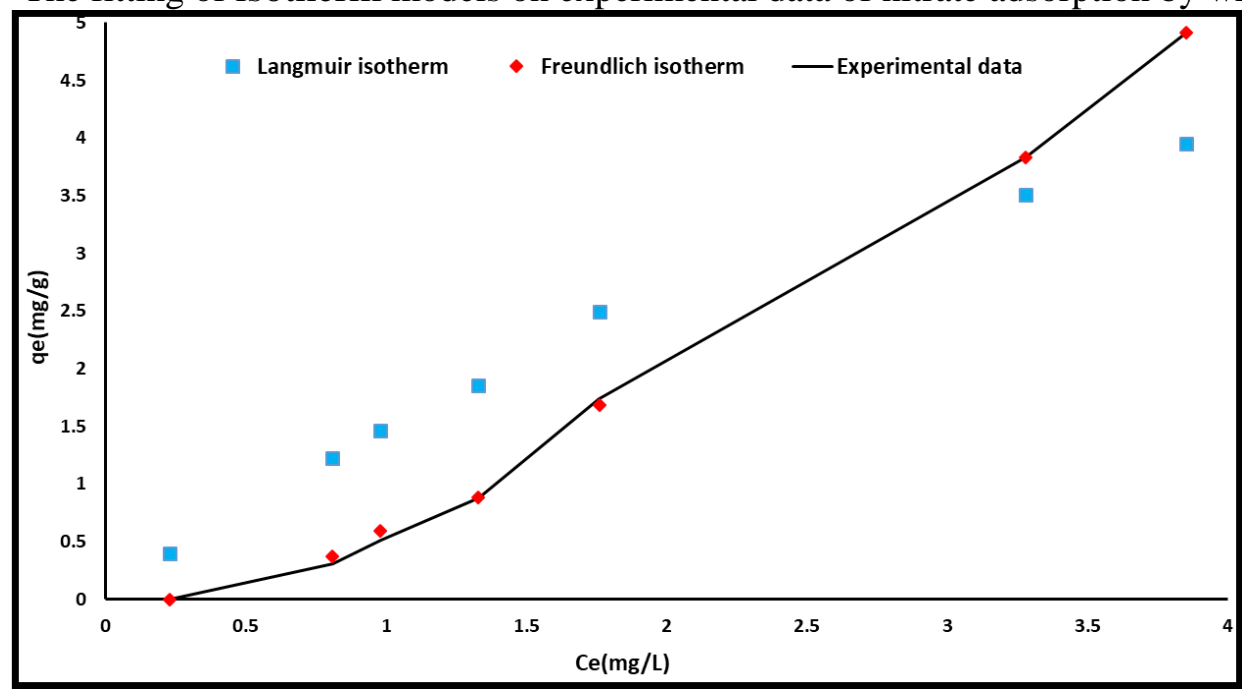

\section{Conclusion}

According to the results of this study, optimum $\mathrm{pH}$ for nitrate adsorption by wheat straw is 6. The results of adsorption kinetics experiments showed that as the contact time increases, the absorption efficiency increases, and the balance time for this study is 140 minutes. At the optimal balance time and $\mathrm{pH}$, the maximum adsorption value was calculated $1.87 \mathrm{mg} / \mathrm{g}$. Also, the results showed that Ho et al. model describes adsorption kinetics data better than Lagergren model. The results of isotherm studies showed that the Freundlich model has a better fit for adsorption test data.

\section{References}

Ahmadpari, H., Shokoohi, E., Falahpour Sichani, B., Namdari Gharghani, E., Rigi Ladez, B. (2019). Evaluation of the most appropriate statistical distribution for monthly rainfall prediction in the Zarrineh river watershed, Specialty Journal of Biological Sciences, 5 (2), 1-9.

Arbabi, M., Hemati, S., Raygan, S., Sedehi, M., Khodabakhshi, A., Fadaei, A. (2016). Evaluation of almond shells magnetized by iron nano-particles for nitrate removal from aqueous solution: study of adsorption isotherm. Journal of Shahrekord university of medical sciences, 17 (6), 92-102.

Bhatnagar, A., Kumar, E., \& Sillanpää, M. (2010). Nitrate removal from water by nano-alumina: Characterization and sorption studies. Chemical Engineering Journal, 163(3), 317-323.

Divband, S., Shirazi, p., Divband, L, Azadi, S., Tishehzan, P. (2014). Kinetics and isotherm adsorption nonlinear models survey for nitrate by titanium dioxide nano particles, Journal of water and sustainable development, 1(1), 35-41.

Farasati, M., Jafarzadeh, N., Boroomand, S., Moazed, H., Abedi Kupaee, J., Seyedian, M. (2013). Use of agricultural nano adsorbents for nitrate removal from aqueous solutions, Iran-water resources research, 8(3), 28-38.

Freundlich, H. M. F. (1906). Over the adsorption in solution. J. Phys. Chem, 57(385471), 11001107.

Hekmatzadeh, A. A., Karimi-Jashni, A., Talebbeydokhti, N., \& Kløve, B. (2013). Adsorption kinetics of nitrate ions on ion exchange resin. Desalination, 326, 125-134.

Lagergren, S. (1898). About the theory of so-called adsorption of soluble substances. J. of Kungliga Svenska Vetenskapsakademiens Handlingar, 24(4), 1-39.

Langmuir, I. (1916). The constitution and fundamental properties of solids and liquids. II Liquids. Journal of the American Chemical Society, 38(11), 2221-2295. 
Marzi, M., Farahbakhsh, M., Shahbazi, K. (2015). Characteristics of nitrate sorption onto activated carbon. Iranian journal of soil and water research, 46(3), 545-553.

Naseri, S., Heibati, B., Asadi, A., Gholestani Far, H., Dargahi, A. (2013). Performance evaluation of modified pumice on removal nitrate from aqueous solution: kinetics studies and adsorption isotherm, Toloo-e-behdasht, 12(1), 143-154.

Nemati sani, O., Sadeghi, A., Dehghan, A A., Asadzadeh, S., Dolatabadi, M. (2014). Removal of nitrate from aqueous solutions using Saccharomyces cerevisiae biosorbent: adsorption isotherms and kinetics. Journal of north Khorasan university of medical sciences, 6 (2), 441-449.

Norisepehr, M., Golbaz, S., Jarghi, S. (2013). Comparision of chitosan function as adsorbent for nitrate removal using synthetic aqueous solution and drinking water, Journal of environmental health engineering, 1 (1), 11-19.

Olgun, A., Atar, N., \& Wang, S. (2013). Batch and column studies of phosphate and nitrate adsorption on waste solids containing boron impurity. Chemical engineering journal, 222, 108-119.

Safdari, M, Qhaneian, M T., Ehrampoush, M H., Babaee, A R., Emamjomeh, M M., Zareii, S. (2015). Study of efficacy of date kernel ash on removal of nitrate from aqueous solutions (isothermic and kinetics study), Journal of Shahrekord university of medical sciences, 16 (6), 48-56. Saunders, L. J., Russell, R. A., \& Crabb, D. P. (2012). The coefficient of determination: what determines a useful R2 statistic? Investigative ophthalmology \& visual science, 53(11), 6830-6832. 